\title{
A CRITICAL ASSESSMENT OF JOHN MILBANK'S CHRISTOLOGY
}

\begin{abstract}
John Milbank is well known for attempting to develop a participatory theology. This article specifically assesses his Christology. The first section provides a synthetic explication of his Christology by focussing on his notions of participation, paradox, poesis, incarnation, the cross, and ecclesiology. The second section provides a critical assessment. The central argument is that Milbank's Christology is inadequate in a participatory sense, because it lacks particularity and personal relationality. This inadequacy is probably due to the way in which he fuses NeoPlatonism and postmodern lingualism in order to construct his ontology. In order to maintain his non-violent and poetic ontological position, Milbank needs to revert to a general, "high" and impersonal Christology, and disregard "low" Christology. However, if one's ontological construction leads to a detached Christology, which does not adequately affirm the central notion of one's theology, serious doubts arise concerning the legitimacy of one's method.
\end{abstract}

\section{INTRODUCTION}

Milbank's theology, as is the case with the Radical Orthodox movement, is to a large degree informed by his resistance to the genealogy of modernism and secularism with its Cartesian epistemology and its striving for a single system of truth based on universal reason. In order to overcome this typical Enlightenment-type of rationality, Milbank (1991:225) proposes that Christian Theology must make a half-turn back to pre-modernity by relying on sources that are not influenced by modernism's strict separation of immanence and transcendence. The central theological framework of John Milbank's theology is the notion of "participation", as developed by Plato and reworked by the Christian tradition, specifically Augustine, Christian

Prof N. Vorster, Northwest University. E-mail: nico.vorster@nwu.ac.za.

Acta Theologica

2012 32(2): 277-298

DOI: http://dx.doi.org/10.4314/actat.v32i2.16

ISSN 1015-8758

(C) UVIUFS

<http://www.uovs.ac.za/ActaTheologica> 
Neo-Platonism, Thomas of Aquino and the nouvelle theologie of Henri de Lubac and Hans Urs von Balthasar. Using the concept of participation, Milbank attempts to overcome the modern dualisms between nature and grace, reason and revelation by proposing a theology that defies the notion that the immanent can function independently of God. Participatory and incarnational theology entails that faith and reason are included within the framework of "participation in the mind of God". No aspect of the natural world or of human experience can, therefore, be viewed in isolation from God or theology (Milbank et al. 1999:4; cf. Smith 2005:17).

This article investigates the Christology of John Milbank. The question arises as to whether Milbank's ecclesial Christology succeeds in providing a sufficient participatory Christology (not a participatory ontology)? In essence, this question pertains to the coherency of Milbank's theology. Is he able to apply his participationist model consistently throughout his theology? If not, why not? The underlying premise of this article is that a sufficient participatory theology needs both a participatory creational ontology and Christology. Without a participatory Christology, a participatory ontology will lack specificity.

Since John Milbanks' Christology is not well known among reformed South African theologians, the first section of this article will explain Milbank's Christology. In order to do so, this article will focus on key concepts in his theology that relate to Christ such as methexis, poesis, incarnation, the cross, atonement, forgiveness and the relationship between Christ and the ecclesia. Milbank perceives truth as being mediated by beauty. The second section of this article will pose some critical questions and assess whether Milbank succeeds in providing an adequate participatory Christology.

\section{JOHN MILBANK'S CHRISTOLOGY}

Milbank's Christology should be understood against the backdrop of his reading of De Lubac's Surnaturel (1946), the teaching of Aquinas and the sophiology of Bulgakov. He also shares Barth's Christological starting point, but, as will be illustrated later, rethinks it in a non-fideistic manner. He shares his doctrine of atonement significantly with Rahner, while he borrows his interest in the Christ event as "narrative" from Balthasar. It is, however, not the purpose of this article to compare or contrast his Christology with that of other thinkers, but rather to examine the participatory character of his Christology. 


\subsection{Participation through paradox}

Postmodernism, according to Milbank, has "invalidated" modernism's approach to the world, as "consisting of fixed essences". Instead, reality consists of "temporary relational frameworks" that are fluid, constantly shifting and always being "re-distributed with greater and greater freedom" (Milbank 1991a:225; Hedges 2010:804). Christian theology could, according to Milbank (1991a:226), "with equal validity imagine temporal processes as reflecting eternity; as the possibility of a historical progress into God". Reality is then perceived as "characterised by flux and ceaseless alterations, so that we cannot know this reality but only join in its occurrence". This stands in contrast to Plato who, for the sake of upholding the possibility of knowledge, postulated the essential being of things, their static eidos, which is not subject to change.

Milbank's Christology is informed by his understanding of creation:

Through its belief in creation from nothing Christianity admits temporality, the priority of becoming and unexpected emergence. Creation is a gift of God, but also a developing order where created difference proceeds from the continuous emanation of divine difference. Existing harmonies, existing extensions of time and space, constantly give rise to new intentions, to movements of the Spirit, to further creative expression, new temporal unravelings of creation ex nihilo, in which human beings must consciously participate (Milbank 1991a:236).

For Milbank, the world is about the reconciliation of being with itself. $\mathrm{He}$ resists the modern idiom of transcendence, inaugurated by Duns Scotus, which separates the finite and the infinite by stating that God and creation exist in the same fashion in being (Milbank 2005:27). Duns Scotus did not relate God to creation through a hierarchical process of emanation, but emphasised God's free and sovereign will. Milbank's criticism is that such a line of thought does not take into account the need for mediation. The participation of the finite in the infinite is, according to Milbank (2009:110), best described by the mediating concept of paradox which falls within the domain of the metaxological (initially, he used the term analogy). Milbank (2009:163-164) describes "paradox" as follows:

Whereas dialectics is concerned with impossible contradiction that must be overcome, paradox is concerned with a coincidence of opposites that can be persisted with. The logic of paradox can also be described as the constitutively relational or metaxological, 
because it is about that which is 'shared' and lies 'between' identity and difference, univocality and equivocality.

Things thus, according to Milbank (2009:164), correspond in terms of their "difference" and differ with respect to their "likeness". There is a continuous interplay between the "same" and the "different" that causes both creative tension and peaceful forms of co-existence (Milbank 2009:167). According to Milbank (2009:170-171),

[t]he infinite is related paradoxically to the finite in the sense that infinite and finite both coincide and do not coincide, they are distant from one another yet united with another. When we see things as identical with their opposites, when we see things as like each other in terms of their differences, we are sensing the involvement of the finite with the infinite.

God's involvement with the immanent exists therein that He is the "giving source" and "inner reality" of everything. Conversely, humanity's relationship with God is paradoxical, because it exists therein that "we are identical with God, only because God is our deepest identity" (Milbank 2009:209). Since everything finds its origin in God, it also finds its ontological modes in the being of God. Creation is thus a gift of God who reminds us of the Giver who is God. Milbank employs the notion of gift as a transcendental category in relation to all the topoi of theology. Creation and grace are gifts, Incarnation is the supreme gift, while the Fall, evil and violence are the refusal of gift (Milbank 2003:ix). He asserts that the only true reality can be a shared reality - the giving of a gift by a Giver. "Giving" is just as transcendental a term as "being", and is inseparable from exchange (Milbank 1995:119, 121). With "exchange", Milbank means that a recipient always has to respond to a gift in gratitude, but not in a similar fashion by giving the same gift back, because this would be an insult. There must be a "non-identical repetition" between gift and "counter gift" (Milbank 1995:125). A real gift, therefore, must "express something of the giver" and yet leave the recipient a certain "mimetic freedom" to respond gratefully. Gift exchange thus involves a "free gift" that you must give, but also "an obligation that is not fulfilled unless you fulfil it in an entirely free way" (Milbank 2011:27). The gift and the Giver can never be identified in an absolute way.

Since the esse of God gives existence to everything and is the existence of everything, the universe is ultimately grounded in God and essentially theocentric. Every sphere of life is innately theological, because all knowledge of creatures are simultaneously knowledge of God. All systems that attempt to function in a non-theological way are at heart "nihilistic" (Milbank 2006:278-279). Milbank's theocentric grounding of reality 
necessarily entails that he disposes with the notion that theology must start from "below". He rather maintains that conceptions of the "below", that is, notions of human subjectivity and relationship, are constituted within the narrative that simultaneously postulates the "above" (Milbank 1991a:226).

The ontological premise that everything is grounded in God necessarily entails that God's intertrinitarian nature will play an important role in Milbank's theological reflection. The doctrine of the Trinity is, according to Milbank, a statement of faith that God is in Himself relationship and because of this the Trinitarian God exchanges love infinitely (Milbank 1991a:234). Because God in Himself is relationship,

God in Himself is also community, and then a community in process, infinitely realized, beyond any conceivable opposition between perfect act and perfect potential (Milbank 1991a:234).

Yet,

God in a manner exists outside God, because He goes outside Himself and returns to Himself: hence the Father, Son and Holy Spirit (Milbank 2009:109).

Through this outgoing and returning, God "births creation and all finitude". The entire cosmos, which includes time and space, is thus part of the unfolding loving relationship of the Trinity (cf. Milbank 2009:145). Milbank perceives the world as a gift exchange between the Father and the Son, a reconciliation between the finite and infinite and, therefore, as part of the inner life of God. The Spirit continuously seeks communion and expresses the exchange between the Father and the Son, while Jesus as historical figure is the incarnated expression of the ontological reconciliation between finite and infinite being (cf. Wisse 2007:352; Milbank 2009:189).

The economic Trinitarian working of Paternal voice - Christ - Ecclesia discloses to us how humanity functions in and through time (Milbank 1991a:236). Human beings are, according to Milbank (1991a:236), images of the Trinity who participates in the Trinity, while the Spirit constantly gives rise to new movements.

Since God is "community in process", knowledge is a "process of learning which is true if divinely illumined". Outside of this process no knowledge of an object is possible (Milbank 1991a:234). If our desires correspond to the Father and Spirit, the Divine Logos illuminates our mind 
(Milbank 1991a:234). Our desire is moved by "infinite lack, the pull of the goal" (Milbank 1991a:235). Christianity thus pursues from the outset

an universalism which is open to difference, new insights, additions and progressions towards God, but make these differential additions a harmony in the body of Christ (Milbank 1991a:227).

Christ, by being first, defines the way to God and also determines the nature of the new ecclesial society. Humanity progresses into deification which entails "a reception of the fullness of Being and a receiving of God" (Milbank 1991a:230).

\subsection{Poesis}

But how does humanity receive God? To answer this, Milbank employs the concept of poesis. If we understand creation to be ex nihilo and through God's word (Logos), language ought to be regarded as primordial and reality as fundamentally linguistic in nature. Language, which for Milbank, includes the entire range of significant human cultural productions, is not representative but constitutive of reality, which means that human existence is poetic in nature. The notion of participation can, according to Milbank, also be extended to language history and culture. Not only do being and knowledge participate in a "God who is and who comprehends"; but human making also participates in a God "who is infinite poetic utterance: the second person of the Trinity" (Milbank 2003:ix).

Poetic existence, according to Milbank (1997:123), can be described as

an activity, mode of knowledge and ethical behaviour which is concerned with aesthetics and the beautiful, that which fits and harmonizes.

Milbank develops his account of poesis under three headings namely poetic activity, understanding, and praxis.

Milbank regards truth as being mediated by beauty. The human being's poetic activity is driven by

its expressive nature and desire to appropriate its environment as a system of value which in the end creates a world of meaning (Milbank 1997:124).

The desire for beauty creates a longing and seeking that cannot be perfectly grasped or possessed (Milbank 1996:42). The product that the human being creates is characterised by "self-exceeding", because we 
come to depend upon a world of meanings that we have constituted ourselves. It possesses a certain virtus of its own such that it cannot be replaced by the subject which is the author (Milbank 1996:42).

The self-exceeding nature of poetic activity underlies poetic understanding. Human beings primarily understand through images and metaphors. These linguistic features make abstract meaning possible by creating concepts of representation that are able to make something present through something else (Milbank 1997:127). However, this creates the question as to whether poetic meaning could be stable? Milbank's response is that we need concrete universals to create stable meaning. A concrete universal is that which harmonises and brings aesthetic unity. This can only be created through the "mediation of the sensus communis" (Milbank 1997:128).

Since poesis is concerned with discernment of forms that are suitable and fitting, and since this can only be done through the means of representation it is not possible to separate poesis from praxis (Milbank 1997:129). Ethical activity is derived from our poetic representations. For instance, in order to understand heroism, we need stories and images of heroes. These poetic representations help us establish adequate human goals that lead to deeper possibilities of human behaviour (Milbank 1997:129).

The poetic nature of human existence leads into humanity's poetic encounter with God. God, of his own free will, finds somewhere between our cultural products that are not truly in our control space to confront us (Milbank 1997:74). Because God is truly transcendent, He never confronts the creature through the I-Thou relationship, but always address the creature as the expressive self. Our poetic quest for telos becomes a quest for God, because the divine reality is the telos of human reality. In fact, God creates the human being as a poetic being in order to connect to human beings. Revelation is thus, according to Milbank, not "an imposition that happens outside normal processes of history, but it is the surplus within poesis itself". Through poesis divine and human creations interconnect, without God interposing in a way that violates natural human intent (Milbank 1997:130). Rather, the Divine overtakes and completes human creations, so that revelation is something positive in addition to reason.

The human being's aesthetic desire makes God's glory attractive for humanity. That is the reason why in history we have noted a quest for a mediator (cf. Milbank 1997:131). The figura of the mediator corresponds to the poetic notion of a concrete universal. Christ is an adequate representation of God to humanity and an adequate representative of God to humanity. He is the concrete universal that creates stability in meaning 
and aesthetic harmony. In Jesus we recognise "the divine overtaking and fulfilling of all human purposes". From a divine perspective, Jesus is the origin of all meaning but, from a human perspective, he is the "inheritor of all already constituted meanings". Jesus thus metaphorically represents all human intent, the word of God as well as the fulfilment of Creation (Milbank 1997:132-133, 139).

\subsection{Incarnation and cross}

The paradoxical relationship between the transcendent and immanent is expressed in the Incarnation (Milbank 1997:132-33, 139). God became "man in order to incorporate us into the Trinity, opening up our realm into the beyond of the infinite life of God". He thus saves us from "materialism and pure immanence" (Milbank 1999b:31). Through the incarnation, the Father "hands over the created realm to filial rule until the eschaton" (Milbank 2010:157).

Christ's incarnation is not about bringing a sacrifice that can offer back creation to God by representing all of humankind before God, but it concerns deification. It is about the foundation of the Church, which is a community of charity and forgiveness. The doctrine of the incarnation identifies Jesus with the divine Logos and establishes the practical relation of the church to Jesus (cf. Milbank 1991a:233). According to Bauerschmidt (1999:424), Milbank attempts to avoid the "extrincism that often attends articulations of incarnation" by shifting priority from Jesus to the church. The Gospels are primarily concerned with a new form of life within a "web of signification", not about Jesus as subject (Bauerschmidt 1999:424). It is not belief in the fact of incarnation that transforms our lives, but it is the translation of the incarnation into a "mode of being" that transforms our lives (Milbank 1991b:315). Within this new mode of being, Jesus is "the space in which all true identities are located; the source, goal and content of all our lives" (Milbank 1991b:325).

To identify Jesus, the gospels resort to metaphors that articulate themselves in spatial and vertical terms and abandon the temporal and horizontal. Incarnation, therefore, "cannot be by the absorbing of divinity into humanity, but only by the assumption of humanity into divinity" (Milbank 1991b:316). Christ's human existence is entirely "derived from the divine person of the Logos by which He is enhypostazised" (Milbank 2010:210). Though Jesus's affinity with God was so strong as to "constitute identity", the identity does not consist in substantial nature, but in an identity of character, hypostatis or persona (Milbank 2003:203). According to Milbank, Jesus was a full integral human being only by virtue of the fact that he was 
a divine person, and that the goodness of divinity completely ensued by grace to his human nature. Even though every specific characteristic of Jesus is entirely human and temporal, his personhood was divine rather than human (Milbank 2010:210).

Since the Gospels are ultimately concerned with a new mode of being, the kingdom of God, which is the universal community of the church, comes before the cross (Milbank 1991b:314). The kingdom is really offered by Christ to humanity, and the cross is the result of the rejection of this offer. This rejection suggests the character of $\sin$. To sin is to "refuse the love of God and to render oneself incapable of recognizing God" (Milbank 1991a:231). It is the ultimate "distorted construct" (Milbank 1997:139).

In a world dominated by evil and violence, a self-offering to God necessarily involves suffering. Since, according to the logic of creatio ex nihilo, to be is entirely to receive, a constant giving up of oneself is the only way to get oneself back and to keep participating in Being (Milbank 1996:52). This is the reason why suffering is "at the heart of Christ's perfect self-offering to God" (Milbank 1991a:231). Milbank (1991a:231) states it thus:

Only God Himself can fully suffer evil - not in eternity, which is beyond suffering - but in the human creation. Hence the necessity for the Deus Homo.

Through his suffering, the "God-man who by His innocence fully sees and so fully suffers, exposes the illusion of self-possession" (Milbank 1996:53). Christ on the cross suffered death, human malice, and the misuse of the law for the sake of the welfare of the political community. Through his suffering, Christ redefines beauty as the "incorporation and transfiguration of the ugly" (Milbank 1996:139). His suffering may then be assumed by us as "the only mode of access to his innocence" (Milbank 1996:53).

The cross is thus not some kind of atonement that effects a change in God's attitude towards us. Such a form of atonement is meaningless, because it can only remain extrinsic to us (Milbank 1991a:231). Atonement rather means:

that the flux is permitted to flow again, that the ever different articulation of our responses continues. Jesus's assuming of the burden of $\sin$ is an atonement because Jesus's response is a nonviolent one: He refuses the violence which would actively distort his own work. Through his crucified body He now makes to us a totally non-violent, unconstraining appeal. Christ did not die on the cross merely instead of us; rather, having uniquely suffered the death of 
the innocent, he calls on all human beings to partake of this death, and in a measure to repeat it (Milbank 2010:45).

Milbank rejects penal substitution theory in no uncertain terms. The danger of a cultic understanding of Christ's death is that it suggests that Christ's death is "a kind of eternal transaction between God and humanity that is a mere extrinsic fact only to be believed in" (Milbank 2003:62-64). However, true gift can never be a transaction; it is by nature "reciprocal and a-symmetric". Christ's abandonment "offers no compensation to God, but raises us up into the eternal gift exchange of the Trinity" (Milbank 2001:552). God has no need to be appeased in order to become reconciled to us; He always and eternally was reconciled in himself. He has no need to forgive since he goes on giving (Milbank 2003:62-64). The atoning nature of Christ's work rather lies therein:

that sin locks one into finitude, and so further into the structures of death and sinfulness. This can be overcome only by the entry of the infinite into the finite through the God-man and the paradoxical identification of the infinite with the finite (Milbank 2010:212).

Redemption, therefore, is not about God forgiving us, since our sins cannot harm God, but rather about his giving us the gift of the capacity for forgiveness (Milbank 2003:62). For Milbank, God's forgiveness is not an extrinsic forensic declaration that individuals are no longer guilty. It is rather an unlimited positive circulation that is allowed to continue (cf. Milbank 2003:48, 64; Boersma, 2005:190). Reconciliation is also no event between us and God, but is rather mediated by God to us, making it effective for us, and so ensuring that we too are reconciled.

Instead of a cultic understanding of Jesus's death, we should regard Jesus's death as almost "inevitable", because his rejection of violence negated the basis of all human, political and social mechanisms that hitherto existed (cf. Milbank 2003:100). Christ is substitute in the sense that the divine Son through His assumed human nature makes the return offering of true worship to the Father - a return that humanity should make but cannot make because of the Fall. An innocent other must first show the way forward of true worship before it thenceforward becomes imitable (cf. Milbank 2003:46). Christ is thus a "sign and perfect metaphor of forgiveness", whereas atonement is "nothing more than forgiveness, because forgiveness is in itself atonement" (cf. Milbank 1991b:325-326, 328). It follows that atonement cannot be "once and for all", but must be continuously renewed through the practice of forgiveness (Milbank 1991b:327). Christ's example must somewhere and somehow be followed and this "mimesis must clearly involve further acts of mutual atoning which 
realizes the hypostatic presence of the Holy Spirit" (Milbank 2003:42). Imitation of Christ is never a straightforward moralism. It is only imitation in the sense that the church is

caught up in the eternal process of participatory exchange, in which believers live by the charismatic gifts that are theirs through the Spirit (cf. Milbank 2003:153).

\subsection{Christ and ecclesia}

For Milbank, grace is about deification, the "gratuitous raising of humanity above itself to God, not a judicial corrective for sin" (cf. Milbank 2005:34, 80). The gift of Christ is the gift of the

Spirit to the church, a gift that is a divine indwelling power in us to begin realize the kingdom of love upon earth (Milbank 2005:38).

The central aspect of salvation, therefore, is the creation of perfect universal community which is "inaugurated by the Incarnation and hypostatic descent of the Spirit on earth" (cf. Milbank 1991a:232; Milbank 2003:105). It is only the primacy of ecclesiology that can remove us from extrincism, because the incarnation of Christ can only be perceived in the existence of the church which "both transmits the signs of atonement and repeats atoning practices" (Milbank 1991b:327). This implies that Christological doctrine is a deduction from ecclesiology (Milbank 1991b:329). The Gospels cannot be read as the story of Jesus, but

as the story of the (re) foundation of a new city, a new kind of human community. Jesus figures in this story simply as the founder, the beginning, the first of many (Milbank 1991b:317).

Genuine ecclesiology, for Milbank, comprises a philosophy of history that recounts the Church's actual concrete intervention in the social order. Christianity essentially involves the claim that the "interruption" of history by Christ and his bride, the Church, is "the most fundamental of events, interpreting all other events" (Milbank 2006:390). Jesus came to

expose the secret of social violence hidden since the foundation of the world and to preach the kingdom as the possibility of a life refusing mimetic rivalry and, in consequence, violence (Milbank 2006:396).

Milbank regards the church as the altera civitas on pilgrimage through this temporary world, its goal is peace and its means are non-coercive (cf. Milbank 2006:382). Because the Church is already, by virtue of its institution, a reading of other human societies, it becomes possible to 
consider ecclesiology as also a sociology, and simultaneously to think of theology as social science (Milbank 2006:382, 383). All political theory is relocated by Christianity as thought about the church, which is a new community that practices a new ethos characterised by non-violence, charity, peace, reconciliation, and forgiveness (cf. Milbank 2006:410). By seeking to

recover the reality of an original peaceful creation beneath the negative distortion of dominium, the church is able to realize the political objectives of justice and virtue that the polis could not arrive at (Milbank 2006:414, 423).

Human relations, therefore, need to be brought within the true asylum of the church.

The new community is empowered by Christ to forgive, suffer and make continuing atonement (Milbank 1991b:317). It is in the church and through "the practise of forgiveness" that we achieve participation (Milbank 2003:x). Human beings receive God by giving practical recognition to Christ as

the fulfilment of human intent by regarding our entire lives as nothing but an interpretation of Christ as presented to us in the Scriptures and in the Sacraments (Milbank 1997:139).

They specifically receive God by partaking in the death of Christ and repeating the event of the cross through their own suffering, because "self-offering to God entails suffering that resumes contact with a wholly positive order of mutual ecstatic giving" (Milbank 2010:45). Christ has abolished the sacrifices of the earthly city, but instead he has

inaugurated a new kind of efficious sacrifice of praise, self-sharing and probable attendant suffering which unites us with $\mathrm{Him}$ in the heavenly city and at the same time totally obliterates all the contours inside and outside which constitute human power (Milbank 1991b:318).

The event of transformation needs to be non-identically repeated and, therefore, made to happen (Milbank 1991b:319). As we offer ourselves in and with Christ, we also participate in the "infinite process of gift exchange" (Milbank 2003:102).

The theme of resurrection and the Church as the body of Christ restores, according to Milbank (1991b:319), concreteness to the notion of incarnation. We can only know God through the community of the body of Christ. The community is what God is like, but God is also unlike the community. It is this inexpressible reality to which the community continues 
to try to respond. If God can only be given content through community, "then speaking of God is not just a matter of words, but also of images and bodily actions" (Milbank 1991a:228-229). The Eucharist allows a direct participation in Christ and works in us the sense that we have now come to share in the divine life as God's children. It is in the Eucharist that we celebrate

a sacrificial gift exchange when God offers himself to us in a dying whose loss is overtaken by a giving (Milbank 1996:54).

Our entire perception is informed by the Holy Spirit, a sensus communis inaugurated in us by Christ as an adequate sense of metaphorical judgement which is the necessary transcendental condition for the adequate concrete universal (Milbank 1996:140).

Through the Spirit, Christ is conceived again in us - though in a linguistic fashion. The Spirit stands in the

interpretative gap between the Father and Son and He acts as the guarantor of the Church's 'poetic' imitation of Christ as exemplar (cf. Bauerschmidt 1999:419).

It is in this sense of continuing to the image of Christ that we genuinely participate in Christ and not as "a kind of sub-personal, quasi-material inclusion" (Milbank 1996:141). The ecclesia is the

infinite resurrected body of Christ composed of faithful who are living offerings to God and who are lured by God who is the ultimate goal of all human life (Milbank 2010:46).

The resurrection is "no proof of divinity, nor a kind of vindication for Jesus's mission". It is rather "the memory of community continuing beyond death" (Milbank 1991b:232). Milbank (2010:43) claims that Paul's theology is informed by such a vision of the resurrected man. We have in Christ already proleptically undergone death (cf. Milbank 2001:552). Being already dead, we can no longer sin or be subject to the law, but we belong to Christ through His body, the church, to bear fruit for God. However, Christ's full "incarnate appearance lies always ahead of us" (Milbank 1991b:319). The longing for a universal resurrection is "a political act for it is the ultimate refusal of all denials of community" (Milbank 1991b:232). Without resurrection there "can never be any final reconciliation" (Milbank 1999:38). In the third age of the "Johannine Church" all will become "sons 
of God" and the world will be restored "through the Spirit to the rule of the Father" (Milbank 2010:157). The world thus anticipates

a final historical event that will be also the final disclosure of the meta-historical secrets of eternal outgoings from God (Milbank 2010:59).

\section{A CRITICAL ASSESSMENT}

There is much to be admired in Milbank's theology. His project to resist secularism and autonomous reasoning through the notion of "participation" is a valid one. We need a participatory and incarnational theology that mediates between Creator and creation in order to overcome the dualisms of secularism. Milbank rightly affirms that there is no autonomous reality, no "reserve of created territory" and that the immanent can only be sustained if it participates in the transcendent. The question, however, is whether the Christology that Milbank proposes really provides us with an adequate participatory Christology?

Some methodological concerns need to be raised first. Milbank's notion that the Western Neo-Platonic and semi-Aristotelian tradition, that is best exemplified in the passage from Augustine to Thomas of Aquino, represents the authentic and pure Christian tradition, but that theology went wrong with Duns Scotus; and Suares seems overly simplistic and symptomatic of a highly problematic interpretation of the historical development of Christian theology. Milbank often refers to the Protestant tradition as theologies of mere imputation that is guilty of extrincism, Biblicism and other distortions. Yet the question is: Why does Milbank regard the Christian Platonic and semi-Aristotelian tradition as the authentic expression of the Christian faith? Why not the biblical tradition from which he diverges radically in his Christology? Is Platonic ontology some kind of philosophical presupposition that is required to make the Christian faith authentic?

A second methodological concern is the eclectic character of Milbank's Christology. He fuses pre-modern Neo-Platonic ontology, which is concerned with the harmonic order of things, with a postmodern lingualism that emphasises the transient flux of reality. It is, however, debatable whether a method that picks the bits it finds acceptable from historically opposing philosophies and then represent it as true Christianity is theoretically sound and theologically credible. Milbank's conflation of different, often opposing, sources to provide a coherent scheme of thought leads to historical inaccuracies. Not surprisingly, historical theologians frequently accuse Milbank of misinterpreting his 
sources, specifically Augustine, Thomas of Aquino, Henri de Lubac and Duns Scotus; to serve his own understanding of authentic Christianity (cf. Wisse 2007; Hankey \& Hedley 2005). We might add the name of Paul, since Milbank's interpretation of the views of Paul in Paul's new moment seems very "Milbankian".

A third methodological concern is that Milbank's Christological premise is characterised by an ontological speculation on the interdivine structural being of God. God's essence is charity which leads to limitless divine selfsharing. Creation is part of a gift exchange between the Father and the Son, and Christ's incarnation attempts to incorporate us into the Trinity. By describing God's essence as charity, Milbank risks subjecting God's nature to the charitable, at the expense of the other attributes of God, to such a degree that the charitable actually becomes the real god within the divine nature that makes God self-excessive (cf. Milbank 2005:41). This contradiction illustrates the problem with theology that regards God's being as intelligible. As soon as one formulates concepts that attempt to explain the being of God, one runs into serious difficulties. Human beings simply do not have the ability to gain an adequate cognitive grasp of the Divine Being, although the Being of God can be postulated. The question is: Does Milbank not employ a priori methods of speculation about God's being in order to fit his theology? Is his apriori speculation not merely human construals that work onwards and upwards transcendentally into God (cf. Olthuis 2005:286)? Would it not be better to reflect on God's acts, speech and communion with creation, rather than on his essence, which cannot be meticulously penetrated? The theologies of the main exponents of Protestantism, namely Luther, Calvin and Barth, differ from Milbank in that their notions of participation are not primarily derived from speculative ontological constructions, but in general from Christology. The reason for this is that the Reformers, as well as Barth, were sceptical of speculative philosophy. Although they did not deny God's essence, they believed that we must form our knowledge of God a posteriory from the revelation God gives us of Himself and His works. Calvin thus states:

\begin{abstract}
We know the most perfect way of seeking God, and the most suitable order, is not for us to attempt with bold curiosity to penetrate to the investigation of his essence, which we ought more to adore than meticulously to search out, but for us to contemplate him in his works whereby he renders Himself near and familiar to us, and in some manner communicates himself (Calvin ICR:1.5.9).
\end{abstract}

In my view, the main problem with Milbank's Christology is the lack of realism and particularity. We might ask whether Milbank's notion of reality as "linguistic" is not a reductionist concept that leads to abstraction at the 
expense of realism. His ontological approach indeed tends to collapse into a form of abstraction that takes on a life of its own. By imposing general truths upon the particular through his fusion of Christian Platonic ontology and a postmodern linguistic meta-narrative, he creates a closed and rather idealistic system of thinking that lacks particularity. Richardson (2003:278) rightly asks:

But how can this 'idealist approach' be realist enough to speak of the 'particular'. How can linguistic idealism, presumable the idea that reality is fundamentally linguistic, provide us with a God to whom we might pray, yet who exists outside the language we pray in.

This lack of particularity is especially evident in his Christology, where linguistic idealism and incarnational ontology obscure the particular identity of Jesus. Biblical notions such as crucifixion, suffering, substitution, atonement, representation, and resurrection are provided with a new content where the "particular" makes way for idealistic theories and concepts that exemplify a new mode of being. For Milbank (1991b:328), the historical concreteness of Jesus is

buried beneath an avalanche of metaphors and typological stories which themselves tend to spell out the mere formal grammar of the 'fact' of incarnation.

The salvational significance of the cross is thus reduced to a hermeneutical and poetic form of liberation that has no particular historical-soteriological significance. Ultimately, the primary narrative of the historical person of Jesus is overtaken by a meta-narrative of the incarnate Logos. Bauerschmidt (1999:417) rightly notes that Milbank's desire to make the "speculative excess" of Trinitarian and Christological doctrine integral to discourse about Jesus seems to run the risk of losing its grounding in the stories of the man Jesus. The direction of Milbank's Christian metaphysics leads away from placing "undue emphasis on the specifics of Jesus life in favour of stressing his relations within the contencation of signs" (Bauerscmidt 1999:423). However, if attention to the historical Jesus is lost, Christian Christology could degenerate into an ambiguous type of metaphysical discourse that deprives Jesus of any particular and specifiable content and remains in the realm of the speculative.

Milbank is so focused upon relinquishing all forms of extrinsic thinking that he dispenses with the whole notion of a covenantal I-Thou relationship between God and human beings (cf. Milbank 1997:74). It appears that Milbank regards the notion of a God that imposes his will from outside the human subject and creation as a "violent" concept. He equates imposition, 
even divine imposition, with violence. His counter-narrative, therefore, emphasises that God does not reveal himself from outside the human being, but in the intrinsic poetic activity of the human subject. Milbank, seemingly, regards the notions of autonomy, sovereignty and contractual relations as inherently "violent", because all of these concepts make use of distinctions between a subject and an object, an I and thou, a self and an other. By setting these categories in conflict with each other, a process of violence and counter-violence is allowed to unfold.

However, when we dispense with the extrinsic qualities of the humandivine relationship, we risk subsuming human and divine nature. In Milbank's theology, the personal relationship between the human and the divine, which lies at the core of the biblical theme of the covenant, seems to make way for a form of panentheism. Although Milbank does not explicitly mention panentheism in his works, his writings certainly contain "latent and underlying panentheistic contours" (Mir 2012:526). His panentheism becomes particularly evident in his view of poesis. God is revealed not from without, but is embedded within culture, language, history and human making. Mir (2012:539) notes:

The relation between human and divine poesis is revealed in that history, culture and language are not alien to the divine but are the divine's actual revelatory unfolding.

Although Milbank indeed develops a participatory Christology, it is a metaphysical participation that is inadequate in a "personal relational" sense. Reconciliation remains a detached metaphysical event between two principles, the finite and the infinite, in the being of God, whereas the personal nature of the reconciliation between God and human beings is nonexistent. In fact, the historical Jesus is a superfluous concept in Milbank's theology, an alien addition to the being of God (cf. Wisse 2007:354). This detached kind of approach is highlighted by Milbank's depiction of God as an impassable God who cannot suffer nor be offended or hurt by sin, and thus does not need to forgive, because he is genuinely transcendent and not merely a higher transcendent reality in the same order as us (cf. Milbank 1997:422). The question is: Why then does Milbank describe God as a God of gift, charity and love? If God is not capable of suffering, why would He be capable of love or charity?

Because of his denial of the I-Thou relationship, Milbank's understanding of forgiveness and atonement departs radically from classical Christianity. For Milbank, there is really no divine forgiveness distinct from human forgiveness. He reduces sin to a mere anthropological concept that concerns interhuman relationships and does not affect the divine-human 
relationship in any "personal" sense. Boersma (2005:192) rightly notes that Milbank cannot accept the notion of God for giving us the guilt or the debt of punishment, because his ontology of peace, which regards violence as a form of non-being, does not allow for punishment. Milbank associates punishment with violence and evil. Of course, when God does not punish, there is no need for Him to forgive either. However, is all violence necessarily evil? Can violence, as Boersma (2005:199) rightly asks, not also be redemptive? Often good violence is needed to counteract and root out bad violence. There is often a necessity for a violence that punishes, protects, liberates, and reconciles. Classical Christianity has traditionally affirmed the need for a kind of redemptive violence in its doctrine on atonement. Milbank's use of the terms "violence" and "power" is complex, because it leads to a conceptual breakdown. He universalises these terms to such a degree that they eventually lose any distinctive content. In the case of atonement, it forces him to do away with any sacrificial understanding of atonement. Milbank views an I-Thou notion of the relationship between God and humanity as "violent".

Closely related to Milbank's concept of forgiveness is the impression that he lacks a sufficiently radical view of the nature of the Fall and sin. Since Milbank depersonalises the relationship between God and the human being, and views reconciliation as mediation between the finite and the infinite realms, the Fall should also be understood in impersonal terms as a loss of participation, rather than as the misdirection and total distortion of creature life. His inadequate understanding of the radical nature of sin ultimately reflects in his rather utopian view of the church.

Finally, Milbank's attempt to shift the subject matter of the Gospels away from Jesus to the church and his identification of the church with the reign of God seems highly contentious, because he runs the risk of subsuming Christology into ecclesiology. In his thinking, God reigns in and through the church, so that the church, in fact, becomes a co-redeemer. Christ fully arrives at his divine personhood only in and through the repetition and substitution of the church. His divine personhood is still taking shape in the life of the church, which completes the atoning work of Christ by continuing to make atonement. However, if Christology is deduced from ecclesiology, as Milbank proposes, Christology is removed from the centre of gravity and replaced by the primacy of ecclesiology. What implications does this have for a truly participatory Christology? Does the institutional church not occupy the space that Christ ought to inhabit in the life of the believer? 


\subsection{Is Milbank's Christology adequate in a participatory sense?}

In the introduction the question was raised as to whether Milbank's Christology is sufficiently participatory in nature. The central argument of this article is that Milbank's Christology is inadequate in a participatory sense, because it lacks particularity and personal relationality - two aspects that are essential for true participation. This is reflected in Milbank's denial of the possibility of an I-Thou relationship between God and human beings; his view of God as an impassable transcendental reality that cannot be offended and does not need to forgive; his negation of the importance of the historical identity of Jesus; his understanding of forgiveness as a human enterprise; his understanding of reconciliation as a metaphysical event between the infinite and the finite; the conceptual and idealistic content that he gives to atonement, substitution and representation, and the primacy he gives to ecclesiology vis-à-vis Christology.

If Milbank's theology is built upon the notion of participation, why would his Christology lack an adequate participatory character? The answer is likely to be found in the manner in which he constructs his ontology. Milbank builds his ontology upon the fusion of a monistic Neo-Platonic view of reality and idealist postmodern linguistics and not, for instance, on the more relational concept of creation ordinances, as is the case in Neo-Calvinism. This fusion enables him to relate all ontological modes of being to God's being and to affirm the metaphysical participation of all things in divine being, but conversely, does not allow him to speak of a personal I-Thou relationship between God and human beings, because an I-Thou relationship is not possible if creature things emanate from God (Neo-Platonism) (cf. Milbank 2003:107), nor if language constitutes reality (postmodern lingualism). Consequently, he needs to revert to a general, "high" and impersonal Christology, and disregard "low" Christology, in order to maintain his ontological position.

However, if one's ontological construction leads to a detached Christology that does not adequately affirm the central notion of one's theology, serious doubts arise as to the legitimacy of one's method.

A truly participatory ontology and theology is only possible if Christology forms the centre of gravity. Ontology needs to be constructed from authentic Christological premises, not from classical, philosophical or postmodern premises. However, Christology can only provide theological and ontological consistency, if the "low" and "high" dimensions of Christology are combined. "Low Christology" prevents excessive and ambiguous speculation by safeguarding the particular and historical 
identity of Jesus, whereas "high Christology" provides an avenue for constructing a participatory ontology. The mystery of the Trinitarian existence of God can, after all, only be penetrated from a Christological perspective, because Christ is the incarnated Word of God who reveals to us the Divine Being in a partial but sufficient sense.

More attention to the importance of the historical Jesus could provide correctives on the overly "high and speculative" nature of Milbank's Christology. It is, therefore, important that biblical scholars and historians continue in their attempt to reconstruct the life of the historical Jesus so that theologians can develop a better understanding of the context within which $\mathrm{He}$ functioned and the political and social forces that $\mathrm{He}$ encountered. These historical insights, coupled with the insights of "high" Christology, will enable theologians to gain a better understanding of the nature of Jesus Christ's work and the theological implications thereof for a truly participatory ontology and Christology.

\section{BIBLIOGRAPHY}

BAUERSCHMIDT, F.C.

1999. The Word made speculative? John Milbank's Christological poetics. Modern Theology 15(4):417-431.

\section{Boersma, H.}

2005. Being reconciled: Atonement as the Ecclesio-Christological practice of forgiveness in John Milbank. In: J.K.A Smith \& J.H. Olthuis (eds.), Radical Orthodoxy and the Reformed tradition. Creation, covenant and participation (Grand Rapids, MI: Baker Academic), pp. 183-205.

Calvin, J.

2008. Institutes of the Christian religion. Translated by $\mathrm{H}$. Beveridge. Peabody: Hendrickson.

Hankey, W.J. \& Hedley, D.

2005. Deconstructing Radical Orthodoxy: Postmodern theology, rhetoric and truth. Aldershot: Ashgate.

Hedges, $P$.

2010. Is John Milbank's radical Orthodoxy a form of liberal theology? A rhetorical counter. The Heythrop Journal LI:795-818.

Milbank, J.

1991a. Postmodern critical Augustinianism: A short summa in forty-two responses to unasked questions. Modern Theology 7(3): 225-237.

1991b. The name of Jesus: Incarnation, atonement and ecclesiology. Modern Theology 7(4):311-333. 
1995. Can a gift be given? Prolegomena to a future Trinitarian metaphysic. Modern Theology 11(1):119-161.

1996. Stories of sacrifice. Modern Theology 12:27-56.

1997. The word made strange: Theology, language, culture. Oxford: Blackwell.

1999a. The ethics of self sacrifice. First Things 91:33-38.

1999b. Knowledge: The theological critique of philosophy in Hamann and Jacobi. In: J. Milbank, C. Pickstock \& G. Ward (eds.), Radical Orthodoxy (London: Routledge), pp. 21-38.

2001. Christ the exception. New Blackfriars 82(969):541-556.

2003. Being reconciled: Ontology and pardon. London \& New York: Routledge.

2005a. Alternative Protestantism: Radical Orthodoxy and the Reformed tradition. In: J.K.A. Smith \& J.H. Olthuis (eds.), Radical Orthodoxy and the Reformed tradition. Creation, covenant and participation (Grand Rapids, MI: Baker Academic), pp. 25-43.

2005b. The suspended middle: Henri de Lubac and the debate concerning the supernatural. Grand Rapids, Ml: Eerdmans.

2006. Theology and social theory: Beyond secular reason. ( $2^{\text {nd }}$ ed.). Oxford: Blackwell. 2010. Paul against bio-politics. In: J. Milbank, S. Zizek \& C. Davis (eds.), Paul's new moment: Continental philosophy and the future of Christian theology (Grand Rapids, Ml: Brazos Press), pp. 21-74.

2011. Transcendence without participation. Stanton lecture 4. [Online]. Retrieved from: http://theologyphilosophycentre.co.uk/.

Milbank, J., Pickstock, C. \& Ward, G.

1999. Suspending the material: The turn of Radical Orthodoxy. In: J. Milbank, C. Pickstock \& G. Ward (eds.), Radical Ortodoxy (London: Routledge), pp. 1-21.

MiLBANK, J. \& ŽıžEK, S.

2009. The double glory, or paradox versus dialectics: On not quite agreeing with Slavoj Žižek. In: C. Davis (ed.), The monstrosity of Christ: Paradox or dialectic (Cambridge, MA: MIT Press), pp. 110-234.

MiR, A. 2012. A panentheistic reading of John Milbank. Modern Theology 28(3):526-560.

OlthuIS, J.H.

2005. A radical ontology of love: Thinking with Radical Orthodoxy. In: J.K.A. Smith \& J.H. Olthuis (eds.), Radical Orthodoxy and the Reformed tradition. Creation, covenant and participation (Grand Rapids, MI: Baker Academic), pp. 277-295. 
Richardson, G.

2003. Integrity and realism: Assessing John Milbank's theology. New Blackfriars: 268-280.

SмITH, J.K.A.

2005. Will the real Plato please stand up? Participation versus incarnation. In: J.K.A. Smith \& J.H. Olthuis (eds.), Radical Orthodoxy and the Reformed tradition. Creation, covenant and participation (Grand Rapids, Ml: Baker Academic), pp. 61-73.

WISSE, M.

2007. Pro salute nostra reperanda: Radical Orthodoxy's Christology of manifestation versus Augustine's moral Christology. Neue Zeitschrift für Systematische Teologie und Religionsphilosophie 49(3):349-376.

Keywords

Christology

John Milbank

Participation

Paradox
Sleutelwoorde

Christologie

John Milbank

Partisipasie

Paradoks 